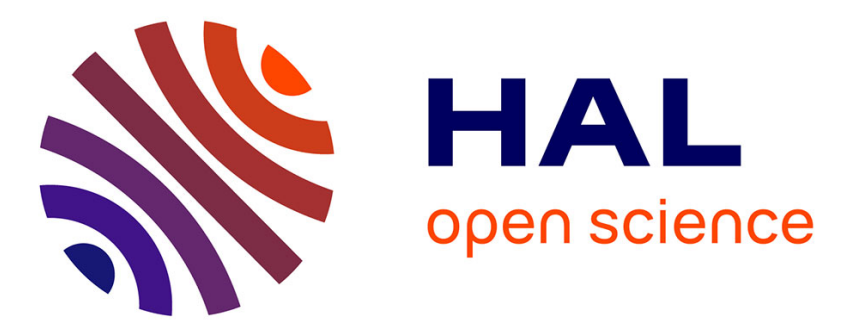

\title{
Horizontal and vertical profiles of ozone, carbon monoxide, non-methane hydrocarbons and dimethyl sulphide near the Mace Head observatory, Ireland
}

R. M. Purvis, J. B. Mcquaid, A. C. Lewis, J. R. Hopkins, P. Simmonds

\section{- To cite this version:}

R. M. Purvis, J. B. Mcquaid, A. C. Lewis, J. R. Hopkins, P. Simmonds. Horizontal and vertical profiles of ozone, carbon monoxide, non-methane hydrocarbons and dimethyl sulphide near the Mace Head observatory, Ireland. Atmospheric Chemistry and Physics Discussions, 2005, 5 (6), pp.12505-12530. hal-00301966

\section{HAL Id: hal-00301966 https://hal.science/hal-00301966}

Submitted on 6 Dec 2005

HAL is a multi-disciplinary open access archive for the deposit and dissemination of scientific research documents, whether they are published or not. The documents may come from teaching and research institutions in France or abroad, or from public or private research centers.
L'archive ouverte pluridisciplinaire HAL, est destinée au dépôt et à la diffusion de documents scientifiques de niveau recherche, publiés ou non, émanant des établissements d'enseignement et de recherche français ou étrangers, des laboratoires publics ou privés. 


\section{Horizontal and vertical profiles of ozone, carbon monoxide, non-methane hydrocarbons and dimethyl sulphide near the Mace Head observatory, Ireland}

R. M. Purvis ${ }^{1, *}$, J. B. McQuaid ${ }^{2}$, A. C. Lewis ${ }^{1}$, J. R. Hopkins ${ }^{1}$, and P. Simmonds ${ }^{3}$

${ }^{1}$ Department of Chemistry, University of York, Heslington, York, YO10 4RR, UK

${ }^{2}$ Institute for Atmospheric Science, University of Leeds, Woodhouse Lane, Leeds, LS2 9JT, UK

${ }^{3}$ School of Chemistry, University of Bristol, Cantocks Place, Bristol, BS8 1TS, UK "now at: Facility for Airborne Atmospheric Measurements, Cranfield University, MK43 OAL, UK

Received: 16 August 2005 - Accepted: 4 September 2005 - Published: 6 December 2005

Correspondence to: J. B. McQuaid (jim @env.leeds.ac.uk)

(C) 2005 Author(s). This work is licensed under a Creative Commons License.
ACPD

$5,12505-12530,2005$

SNAP

R. M. Purvis et al.

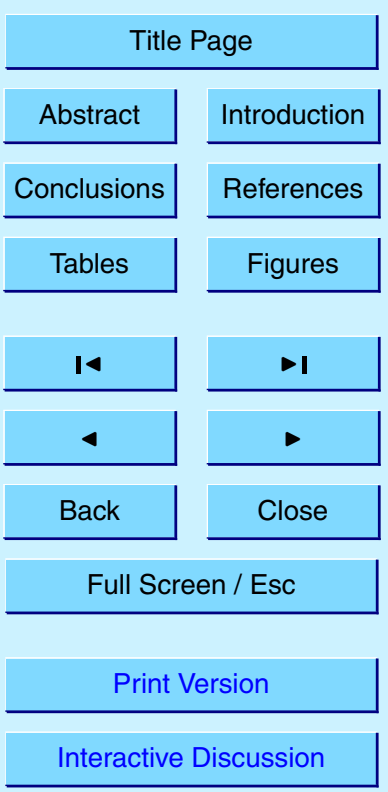

EGU 


\section{Abstract}

The distribution of trace gases upwind and above the Mace Head Atmospheric Research Station, Ireland has been determined using measurements made from aircraft. The observations indicate excellent agreement between most non-methane hydrocar5 bons, dimethyl sulphide (DMS) and ozone measured at the surface, at $390 \mathrm{~m}$ overhead and in upwind boundary layer regions of the coastal Atlantic. Vertical profiles above the observatory indicated that local convective events result in a marine influence being detected at $3 \mathrm{~km}$ and above. The observation of isoprene from maritime sources at these levels was indicative of very rapid uplift on the hour timescale. Measurements of trace gases were also made directly upwind of the observatory over coastal regions and as far as the deep open ocean beyond the continental shelf. A maximum of $240 \mathrm{pptV}$ DMS was observed in the boundary layer near to the shelf region, declining to a concentration of around $40 \mathrm{pptV}$ at the coastline. The upwelling of nutrient rich waters at the ocean shelf location may be a possible explanation for the high abundance of DMS in these regions. The observations suggest that this region, some $150-200 \mathrm{~km}$ from the observatory, would under these environmental conditions have a major influence in the determining the DMS observed on-shore. The spatial distribution of ethene within boundary layer over coastal and deep waters differed significantly from DMS with an almost uniform abundance over all ocean regions.

An important aspect of ground atmospheric observational campaigns, particularly those at coastal sites within an emphasis on determining processes in maritime air, is the degree to which it is representative of air being sampled. A particular concern is the influence that local surroundings and topography have on the target process or species to be studied. The North Atlantic Marine Boundary Layer Experiment NAMBLEX took place over a six week period during summer 2002 at the Mace Head Atmo-
ACPD

$5,12505-12530,2005$

SNAP

R. M. Purvis et al.

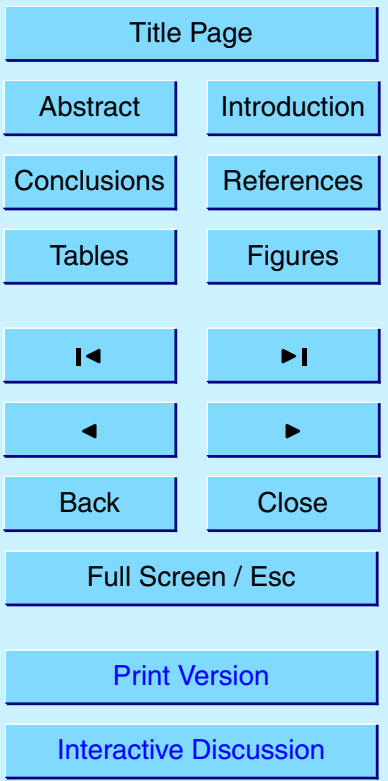

EGU 
spheric Research Station (MH) on the west coast of Ireland (see Heard et al., 2005). $\mathrm{MH}$ is an interesting and widely used observation location as it experiences a range of clean and polluted air masses; trans-Atlantic, Arctic/sub Arctic, tropical maritime, European outflow and local; allowing both long term measurements (Simmonds et al., 5 2004) and specific oxidative and physio-chemical processes in varying air mass types (e.g. Carslaw et al., 1999). Previous observations have indicated that the local intertidal zone impacts significantly on a number atmospheric processes particularly those linked with halogen cycles, through local emissions from macroalgea (Saiz-Lopez and Plane, 2004; Carpenter et al., 1999). This has a notable influence at low tide and in 10 westerly winds. Whilst such local emissions may have a significant impact on particular in situ processes the effects on gaseous species that do not participate in such halogen mediated cycles on a micrometeorological timescales may only be small. The objective of this work therefore has been to determine whether the air sampled at a coastal location such as $\mathrm{MH}$ is representative of boundary layer air over the coastal and open ocean when considered from the perspective of ozone $\left(\mathrm{O}_{3}\right)$, carbon monoxide $(\mathrm{CO})$, non methane hydrocarbons (NMHC) and dimethyl sulphide (DMS). Observations were made in the horizontal domain North and South of the station along the coastline, upwind of the station to the edge of the continental shelf, and in the vertical domain through profiles between $300 \mathrm{~m}$ and $3200 \mathrm{~m}$.

The ocean as a source of many hydrocarbons has been established for many years, although it is poorly quantified in terms of magnitude and homogeneity of emissions. It is has been estimated that global emission of propane by the oceans may be around $4 \mathrm{MT} \mathrm{C} \mathrm{yr}^{-1}$ (Bonsang and Lambert, 1985) compared to a global continental production of $60 \mathrm{MT} \mathrm{C} \mathrm{yr}^{-1}$. The emission of the relatively unreactive alkanes is believed to occur continuously, a product of constant evasion from the ocean surface and determined by transfer velocity and the concentration gradient across the interface. However, for the more reactive alkenes a distinct diurnal cycle with a maximum at solar noon has been observed for species such as ethene and propene in clean marine air at $\mathrm{MH}$ (Lewis et al., 1999). From this 1999 study the alkenes were shown to correlate strongly with so-

ACPD

$5,12505-12530,2005$

\section{SNAP}

R. M. Purvis et al.

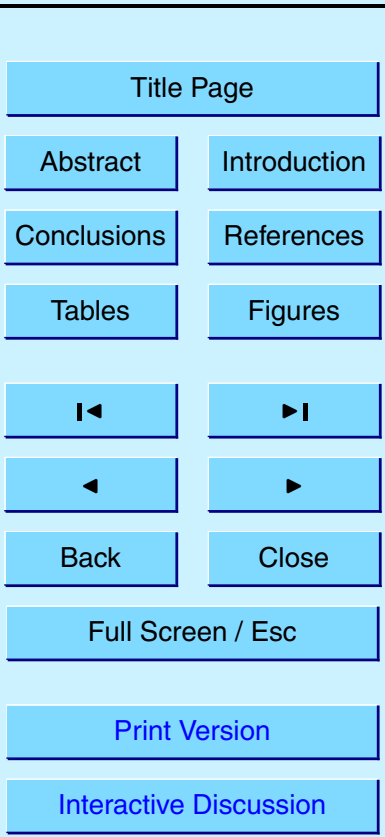

EGU 
lar flux, suggesting a photo-initiated production mechanism for the alkenes close to the sea surface. Most unsaturated compounds are believed to be formed by such photodegradation but the most reactive compound, isoprene, is believed to be produced by a different biological method (Shaw et al., 2003). Broadgate et al. (1997) showed good 5 correlation between isoprene and the chlorophyll content of water, maintained throughout the year. Uncertainties remain however over whether the alkenes observed at $\mathrm{MH}$, which provide a noticeable perturbation of local $\mathrm{OH}$ chemistry, result from intertidal and coastal sources or whether they are representative of a wider more distributed open ocean source.

10 DMS plays an important role in controlling the $\mathrm{OH}$ concentration of the marine atmosphere and is thought to be the major component in the formation of non-sea-salt sulphate. The subsequent possible impacts of DMS have been widely discussed, with the hypothesis that DMS influenced aerosols may act as cloud concentration nuclei, with effects on cloud albedo and climate (Charlston et al., 1987). Bassford et al. (1999) 15 used measurements at $\mathrm{MH}$ in conjunction with airmass trajectories to construct an inverted probability map for DMS emission regions. This indicated that the vast majority of DMS observed at the MH site had been transported significant distances from the mid Atlantic. The conclusion was somewhat at odds with concurrent ship borne observations of Baker et al. (2000) which indicated that the majority of DMS arriving in westerly air to $\mathrm{MH}$ was attributable to local coastal sources. Aircraft observations reported here will attempt to investigate this further.

$\mathrm{CO}$ and $\mathrm{O}_{3}$ have been measured long term at the $\mathrm{MH}$ station as part of the Global Atmospheric Watch (GAW) and the Advanced Global Atmospheric Gases Experiment (AGAGE) networks, operated by the WMO and NASA respectively and the data from which has been widely used e.g. Derwent et al. (1998) and Simmonds et al. (2004). The ozone instrument used for aircraft observations was calibrated simultaneously with the $\mathrm{MH}$ surface instrument, such that at following calibration no more than $1 \mathrm{ppbV}$ difference was observed for an approximately $30 \mathrm{ppbV}$ ambient concentration when averaged over $10 \mathrm{~min}$ (J. D. Lee, personal communication).

\section{ACPD}

$5,12505-12530,2005$

\section{SNAP}

R. M. Purvis et al.

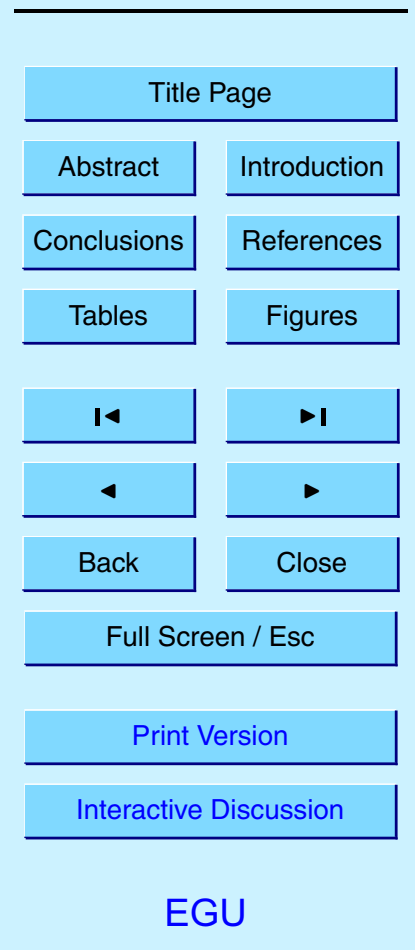




\section{Experimental details}

As part of the NAMBLEX field campaign, the SNAP project (Supporting NAMBLEX with an Airborne Platform) carried out a number of flights in the area around the Mace Head Observatory. All data were collected onboard the NERC Dornier 228-101 research air5 craft operated by the Airborne Remote Sensing Facility (Oxford Airport, Kidlington, UK). Whole air samples were collected in both 3 litre silica passivated stainless steel canisters (Thames Restek, UK) and 1.2 litre electro polished stainless steel canisters (Rasmussen, USA) pressurised to 2.5 atmospheres using an all-stainless steel assembly double headed bellows pump (Metal Bellows, USA), drawing air from the forward

facing air sample pipe (3/8" OD PFA tube). Air samples were analysed within $24 \mathrm{~h}$ using an automated gas chromatograph with a flame ionisation detector, more extensive details of the instrument are given in Hopkins et al. (2002). Automated analysis was performed with $1 \mathrm{~L}$ aliquots of air being withdrawn from the sample canister and dried using a condensation finger. Samples were pre-concentrated onto a multibed carbon 15 adsorbent trap held at $-30^{\circ} \mathrm{C}$ and then heated to $400^{\circ} \mathrm{C}$ and transferred in a stream of helium to an $\mathrm{Al}_{2} \mathrm{O}_{3}$ porous layer open tubular capillary column (Varian, Netherlands) for separation. Peak identification and calibration of $\mathrm{NMHC}$ was made by reference to a 1-10 ppbV level 27 component hydrocarbon standard mixture (National Physical Laboratory, Teddington, UK). Detection limits for individual NMHCs ranged between $6 \mathrm{pptV}$ (for propane) and $0.5 \mathrm{pptV}$ (for isoprene) dependant on molecular weight and chemical structure. A minimum signal to noise ratio 3:1 was considered to be the limit of quantification (LOQ), and 1:1 the limit of detection (LOD).

CO measurements were made with a commercial fast response resonance fluorescence instrument (Gerbig et al., 1996, 1999) (AeroLaser GmbH, Garmish, Germany)

which was fitted with a Nafion dryer to remove water vapour. Absolute calibration was made before and after each flight using a standard containing 1 ppmV CO in synthetic air (Air Products, UK). Blanks were determined using a filter containing Hopcalite (Molecular Products, Thaxted, UK) to remove $\mathrm{CO}$ from ambient air and were carried out

ACPD

$5,12505-12530,2005$

SNAP

R. M. Purvis et al.

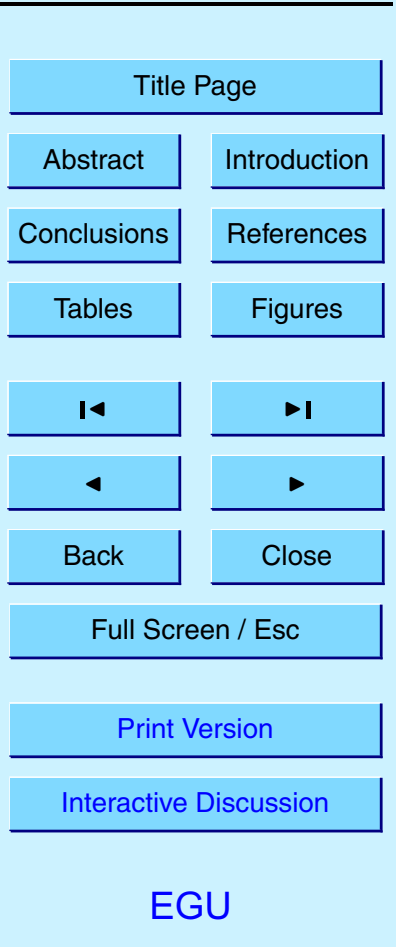


every 20 min during the flight. The linearity range for the instrument was $0-100 \mathrm{ppmV}$ and the detection limit was $<1.5 \mathrm{ppbV}$ for a $1 \mathrm{~s}$ interval.

Ozone measurements were made with a UV photometric analyser (Model 49C, Thermo Environmental Instruments Inc., USA). Spikes occurred in measurements 5 taken during vertical profiles due to humidity and pressure changes and so therefore only data from level runs once the instrument had re-equilibrated are presented in this paper. $\mathrm{O}_{3}$ measurements at Mace Head were acquired every $10 \mathrm{~s}$, with a UV spectrometer (Model 8810, Monitor labs San Diego, CA) and recorded as hourly averages. Calibration is performed every three months against a primary UV photometer (Sweeney 10 and Stacey, 1992). Mace Head CO measurements were recorded every 30 min using using a hot mercuric oxide reduction gas detector (Trace Analytical Inc, Newak, USA, model RGA3), alternating between a calibration standard and ambient air.

\section{Results}

Flights were made from Galway International Airport during August 2002. Each flight 15 was around four hours in duration and covered areas around the Mace Head Atmospheric Research Station ( $\mathrm{MH})$. Two flights are reported in this paper, one outwards from the observatory to the continental shelf region of the Atlantic Ocean and one in a North-South direction along the coast line centred around $\mathrm{MH}$ (Table 1). Flight tracks determined by GPS are shown in Fig. 1.

\subsection{Vertical Profile flight (VP)}

The vertical distribution of gases over $\mathrm{MH}$ was investigated using a series of stacked runs at varying altitudes over the observatory. Each run was approximately $120 \mathrm{~km}$ long orientated along the coastline in an approximate N-S direction (Fig. 1). The meteorological conditions were favourable for this flight with established westerly flow, scattered cloud and the absence of frontal activity. A series of level runs at differing altitudes were
ACPD

5, 12505-12530, 2005

SNAP

R. M. Purvis et al.

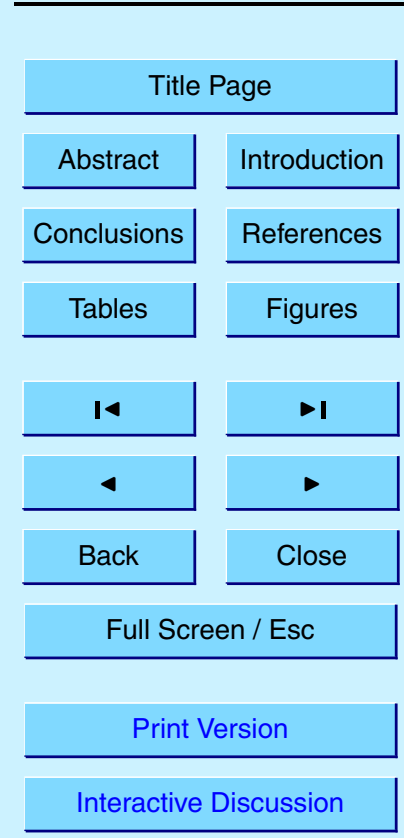

EGU 
performed using the co-ordinates of $\mathrm{MH}$ as a centre point at $390 \mathrm{~m}, 1050 \mathrm{~m}, 1600 \mathrm{~m}$, $2200 \mathrm{~m}$ and $3150 \mathrm{~m}$ (Fig. 2a). The lowest level run (Run 1) provided the opportunity for the most direct comparison between the Mace Head site instruments and the aircraft measurements. Ground data has been averaged over the time of the entire flight 5 resulting in the comparison of the average of $4 \mathrm{NMHCs}$ samples on the ground with 3 samples from the aircraft on this Run 1. All ground based instruments sampled from manifolds which extended above $20 \mathrm{~m}$, this being thought to be above the height of the internal boundary layer at Mace Head as discussed in Norton et al. (2005).

Most NMHC show good agreement between the $390 \mathrm{~m}$ level and the surface (Ta10 ble 2). Both anthropogenic tracers, such as acetylene, and the ocean emitted $\mathrm{C}_{2}-\mathrm{C}_{4}$ hydrocarbons all agree to within the uncertainty of the observations. The $\mathrm{C}_{4}$ and $\mathrm{C}_{5}$ alkanes are the exception, with significantly higher concentrations being measured at the site than on-board the aircraft. The levels observed are sufficiently high for an anthropogenic source to be considered most probable, given that although a sea to air flux exists, this sustains only low single figure pptV concentrations under typical marine conditions. There is no immediate explanation for the elevated levels at $\mathrm{MH}$, although a very local source near $\mathrm{MH}$ cannot be ruled out. Previous values for these species in westerly air at $\mathrm{MH}$ are in line with those made from the aircraft (e.g. Lewis et al., 1999, typically 1-3 pptV). DMS displayed agreement to within $20 \mathrm{pptV}$ with significant spread in values determined from aircraft, but with a relatively homogenous set of values from the ground observations. The variability in DMS emissions by ocean location is know to be great and the observations suggest that within an air stream on the hour timescale variability is low, but crossing between air streams (e.g. N-S across westerly flow) of differing geographic origins results in wider variability.

25 Agreement between surface ozone measurement and at $390 \mathrm{~m}$ level was excellent. The variability in the N-S cross-section was relatively low indicating significant surface homogeneity in ozone on these spatial scales.

There is a large discrepancy between the CO measurements on the ground and in the air (a difference of $31.5 \mathrm{ppbV}$ is observed). To investigate this both instruments

\section{ACPD}

5, 12505-12530, 2005

\section{SNAP}

R. M. Purvis et al.

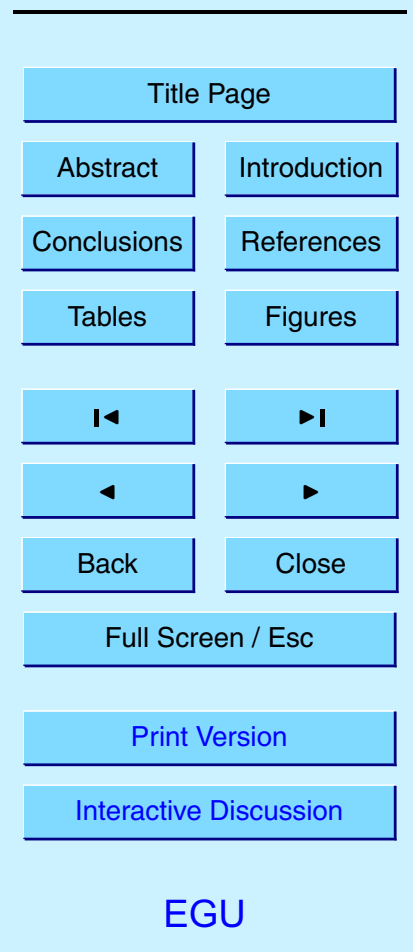


were subsequently run in parallel at the observatory site. These ground measurements made over a period of 3 days showed a consistent offset of around $31 \mathrm{ppbV}$ between the fluorescence and the GC method. Intercomparison of standards made in pure synthetic air, resulted in good agreement (to within $\sim 3 \mathrm{ppbV}$ ) but when real air standards 5 were used, an offset appeared. If the offset between instruments is taken to be relatively constant then the surface observatory and $390 \mathrm{~m}$ measurements are in good agreement.

The vertical distribution within the boundary layer is strongly dependent on meteorological processes (Bonsang et al., 1991). Under westerly conditions mixing within 10 the boundary layer is relatively efficient and a well mixed distribution of species such as NMHCs may be expected. In the absence of frontal or convective activity a decoupling between the boundary layer and free troposphere would also be expected. A decease in mixing ratio for ocean emitted species would be intuitively expected across this boundary. The vertical gradient in anthropogenic tracers such as ethane and propane

over the oceans may be less straightforward since long range transport under westerly conditions to Europe generally occurs away from the surface at higher levels, and it is possible that free tropospheric-mixing ratios may well exceed those with the MBL.

The vertical profiles for ethene, isoprene and DMS (all ocean emitted species) and anthropogenic species (ethane, acetylene and $\mathrm{CO}$ ) are shown in Fig. 2b. The average mixing ratios for selected hydrocarbons, ozone and $\mathrm{CO}$ are shown in Table 3. For the first three runs, a decrease in concentration with increasing altitude occurs for the shorter lived hydrocarbons, such as ethene and isoprene ( $\tau=16.3$ and $1.4 \mathrm{~h}$, respectively, at $[\mathrm{OH}]=2.00 \times 10^{6}$ molecules $\mathrm{cm}^{-3}$ ) (Atkinson, 1997). At $1.6 \mathrm{~km}$ the mixing ratios of these compounds drop below the detection limit of the instrument. This is not the case for the longer lived hydrocarbons and for $\mathrm{CO}$ where an increase in concentration occurs with altitude. A similar pattern to the anthropogenic species is seen for DMS. For Runs 4 and 5 the mixing ratios for the shorter lived species begin to increase once more. An interpretation of this set of profiles is that below around $1000 \mathrm{~m}$ the air is characterised by low $\mathrm{CO}, \mathrm{O}_{3}$ and significant alkenes (implied to be from a sea source)
ACPD

$5,12505-12530,2005$

SNAP

R. M. Purvis et al.

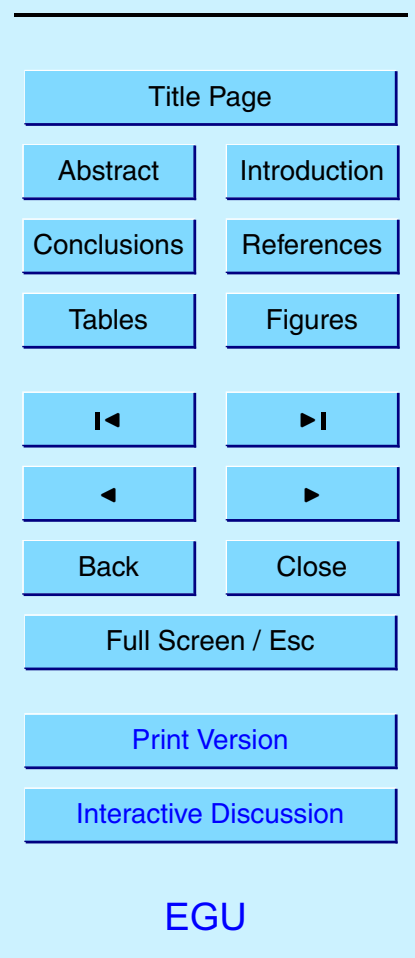


and high DMS. There is a layer at around $1600 \mathrm{~m}$ of higher CO, long lived NMHCs and some DMS but low alkene, and finally an upper region with high $\mathrm{CO}$ but also with apparent oceanic influence.

Five day back trajectories calculated by the NOAA HYSPLIT Model (Draxler and 5 Rolph, 2003) show a distinct difference in trajectory path in the vertical extent between Runs 1-2 and Run 3 (Fig. 3). The first two runs intercepted air masses that had been in contact with the sea surface for several days prior to very recent ascent to the interception level. Run 3 however although from a similar geographic origin but had been ascending over the full period of trajectory and may have been above the boundary layer

10 for much of $24-48 \mathrm{~h}$ prior to interception. This descriptions fits well with the lower levels of alkenes observed in Run 3, although implies, using only a trajectory interpretation, a relatively remote source for DMS given its elevated levels in this level. Run 4 shows similar chemical characteristic to Runs 1-2 and the trajectory path supports this, with initial ascent, then decent into the boundary layer closer to surface followed by ascent 15 to the interception point. The final level in Run 5 is clearly from a very different region with notable elevations in $\mathrm{CO}$ and almost all NMHCs and DMS. Anthropogenic tracers such as $\mathrm{CO}$ and acetylene show similar vertical distributions with enhancements at Run 3 and Run 5.

The mixing ratios of the alkenes and DMS above the layer in Run 3, show levels 20 comparable to boundary layer values at $3.1 \mathrm{~km}$. Based purely on atmospheric lifetimes and trajectories this is somewhat inconsistent. Whilst trajectory calculations follow advective processes with some degree of accuracy, convection within such calculations is poorly described. The conditions under which these observations were made included scattered cumulus at around the $1500 \mathrm{~m}$ level. It therefore seems highly likely that the 3 was in a cloud free region. This would offer an explanation for the apparently mixed characteristics in for example Run 5, which show significant elevation in the longer lived anthropogenic tracers, whilst also showing a maritime influence in the form of DMS and isoprene.

\section{ACPD}

$5,12505-12530,2005$

\section{SNAP}

R. M. Purvis et al.

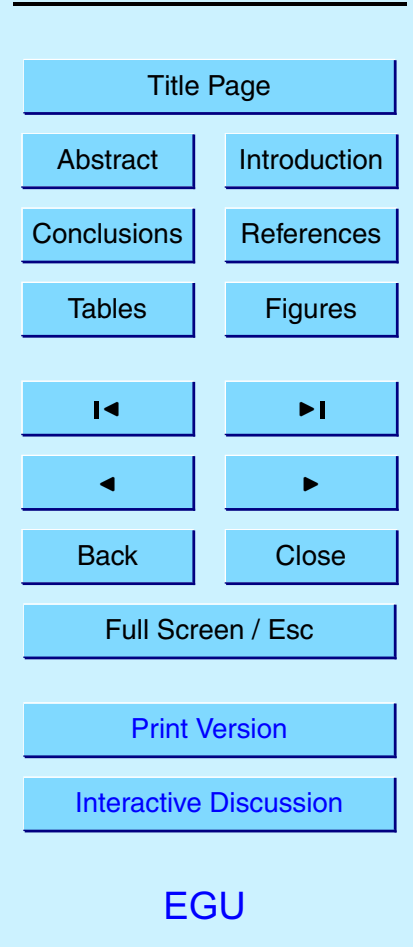


The non-zero values for extremely reactive species such as isoprene suggests that such uplift was occurring from surface to $3 \mathrm{~km}$ in only a few hours. Similar observations were made in ACE1, reported by Blake et al. (1999), where enhanced mixing ratios of DMS were found between 2 and $4 \mathrm{~km}$. The maritime influence at altitude was observed 5 during an ACE1 flight sampling outflow from large cumulus clouds (Clarke et al., 1998). The limitation of canister samples is highlighted by this type of study, where the small number of data points taken over a large geographic region is severely influenced by small scale features such as convective cells.

The differences in chemical composition observed over a relatively small altitude 10 range can be further illustrated using the ratio of $\mathrm{CO}$ to $\mathrm{O}_{3}$ (Fig. 2c). Run 1 shows little correlation between the two compounds, but data are clustered tightly indicating homogeneity. The higher levels each show unique clustered points, however although qualitatively the slopes of $\mathrm{CO}-\mathrm{O}_{3}$ plots are often use to infer photochemical $\mathrm{O}_{3}$ production or loss, the limited chemical dataset and number of points, makes this rather speculative for this flight. Perhaps the most stand out cluster of points is for Run 5 where both high $\mathrm{O}_{3}$ and $\mathrm{CO}$ are observed, albeit with convective influence from the marine boundary layer below. A possible explanation for this may lie in long range transport of emissions from Northern America and Canadian originating from forest fires. These are known to be a major source of $\mathrm{CO}$ and other air pollutants on a global scale (Crutzen and Andreae, 1990) and can produce large amounts of haze and smoke with substantial horizontal and vertical transport. Inspection of CO/acetylene ratios (Fig. 2c) also suggest that the elevated $\mathrm{CO}$ observed on Run 5 is photochemical in origin since the ratios seen at this level fall off the line derived from ratios from the other 4 runs.

$25 \quad$ Waibel et al. (1999) presented measurements of highly elevated (approximately $300 \mathrm{ppbV}$ ) CO concentrations in the tropopause region over Europe during 1994, which were shown to be a result of boreal fires in Canada. In late July/early August, 2002 severe forest fires occurred in many parts of Canada (Canadian forest service, http://www.nrcan.gc.ca/cfs) and emitted pollutant gases into the free troposphere due

\section{ACPD}

$5,12505-12530,2005$

\section{SNAP}

R. M. Purvis et al.

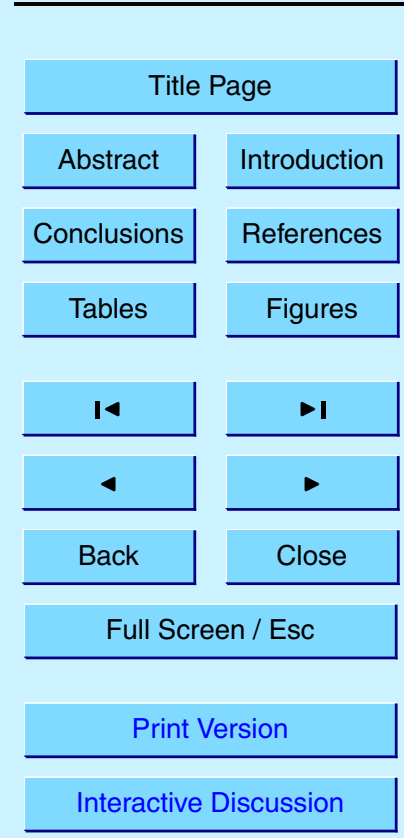

EGU 
to the buoyant convection above the fire spots (Harriss et al., 1992). The back trajectories show (Fig. 3) that five days earlier the air mass had been over Baffin Island, east of the North West Territories, Canada, at an altitude of around $2 \mathrm{~km}$, it is possible that the air mass had come into contact with plumes from forest fires prior to the 5 calculated trajectory or that the plumes had been transported further west in the previous five days. It is not necessarily true that photochemical production of ozone would occur within these forest fires plumes as it is possible that they are transported behind a cold front, with the low temperature and faster dilution of anthropogenic pollutants leading to less favourable conditions for local or regional photochemical ozone produc10 tion (Wotawa and Trainer, 2000). The synoptic analysis for the 6 August 2002 (Norton et al., 2005) has a cold front situated off the west coast of Ireland which could be responsible for the transport of the plume from Canada over the Atlantic Ocean. During the Intercontinental Transport of Ozone and Precursors project in summer 2004 elevated $\mathrm{CO}$ was observed in the mid troposphere of the north Atlantic at concentrations 15 in excess of 500 ppbV, back trajectory analysis clearly showed that the air masses had been influenced by intense fires in Canada (Pfister et al., 2005).

\subsection{Continental Shelf flight (CS1)}

A flight was conducted to investigate the differences in trace species of oceanic origin (particularly DMS and reactive alkenes) between coastal waters and deep-ocean be20 yond the continental shelf. Continental shelf flight one (CS1) was carried out on the 8 August 2002. The position of the continental shelf relative to $\mathrm{MH}$ is around 200 miles offshore (Fig. 1) (approximately $-15^{\circ} \mathrm{W}$ ) and is sufficiently close that the boundary layer over both coastal and deep water could be sampled within a single flight. CS1 was carried out under westerly air flow and observations at $\mathrm{MH}$ indicated that air was from the satellite image at 12:52 GMT by Dundee Satellite receiving station) preceding a frontal system in central North Atlantic Ocean.

The flight track is shown in Fig. 1, with flight out to the continental shelf at $3 \mathrm{~km}, \mathrm{a}$ 12515
ACPD

5, 12505-12530, 2005

SNAP

R. M. Purvis et al.

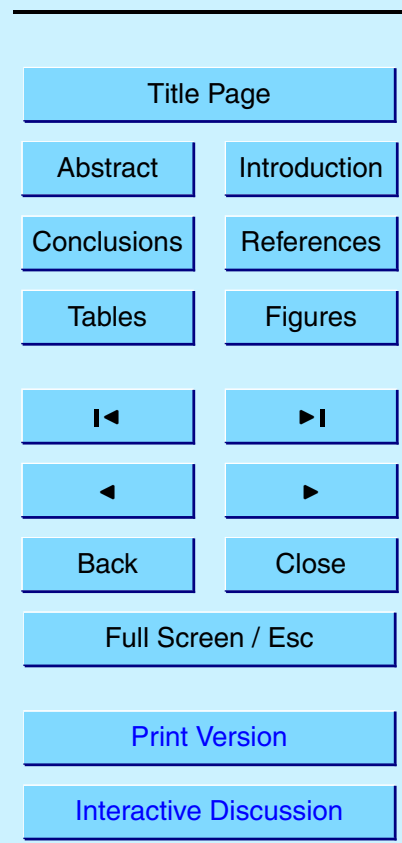

EGU 
profile down in to the boundary layer and a return along the same track to $\mathrm{MH}$ at a lower altitude within the boundary layer.

The time series for $\mathrm{CS} 1$ is shown in Fig. $4 \mathrm{a}$, for $\mathrm{CO}, \mathrm{O}_{3}$, DMS and acetylene. DMS shows significantly greater variability in mixing ratios when compared to an anthro5 pogenic tracer such as acetylene or $\mathrm{CO}$. Vertical profiles for both biogenic and anthropogenic species and are shown in Fig. 4b. Similar to DMS, ethene shows larger variability in its mixing ratios compared to anthropogenic markers. The average profile for DMS and ethene is comparable to the vertical profile observed during the vertical profile flight (Fig. 2b), decreasing above $1500 \mathrm{~m}$, where they reduce to virtually zero, 10 but with some elevated observations at around $3 \mathrm{~km}$. The average mixing ratios for a range of compounds at $400 \mathrm{~m}$ and at $3 \mathrm{~km}$ are shown in Table 4. Figure 4a shows however that there is very wide variability in DMS in this outbound high level $3 \mathrm{~km}$ run, with only sporadic regions at $3 \mathrm{~km}$ with higher DMS. This gives a strong indication that the DMS observed at this level is from the local MBL via convection rather than from 15 longer range transport.

Ozone and $\mathrm{CO}$ relationships are also suggestive of localised uplift of marine boundary layer air to the free troposphere (Fig. 4c). Run 1 encountered three distinct air mass types; highlighted in Fig. 4c. Region A corresponds to low ozone and $\mathrm{CO}$ values but enhanced DMS and ethene, (uplifted marine air), B a period of high ozone ( $<80 \mathrm{ppbV}$ ), $\mathrm{C}$ more processed air mass with typical background free tropospheric values. Region A, the marine uplifted air, has an almost identical $\mathrm{CO} / \mathrm{O}_{3}$ relationship as those observed for Run 2 and Run 3, both of which took place well within the boundary layer.

The objective to identify any differences in boundary layer DMS over deep open ocean and in coastal waters was highlighted earlier. Although both ethene and DMS are ocean emitted species their sources and observed distributions seen in this data are quite different. As the aircraft enters the marine boundary layer (Fig. 4d), the concentration of DMS increases rapidly to a maximum of $240 \mathrm{pptV}$ at $-13.5^{\circ} \mathrm{W}$, then it decreases closer to shore with to a concentration of around $40 \mathrm{pptV}$ at $-11.5^{\circ} \mathrm{W}$. This compares well with the site measurement of $52 \mathrm{pptV}$ made at 15:00 UT on this day.

\section{ACPD}

5, 12505-12530, 2005

SNAP

R. M. Purvis et al.

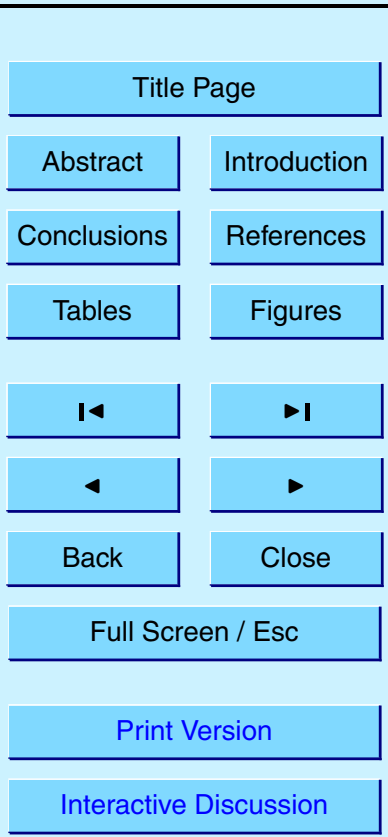

EGU 
Position data from the aircraft indicates that the descent into the boundary layer, made along the E-W axis, enters the boundary layer (estimated as being $1400 \mathrm{~m}$ AMSL), just at the shelf region itself rather than over the deep water. This is clearly not optimal, but was driven by range limitations of the aircraft.

$5 \quad$ The distribution in boundary layer DMS is particularly interesting given the formation mechanisms for its production. DMS is believed to be derived from biogenically produced dimethylsulfoniopropionate (DMSP), which is produced from phytoplankton and its formation is dependant on environmental factors such as light, temperature, salinity and nutrient availability (Charlson et al., 1987; Anderson et al., 1992). It may postulated 10 therefore that in the margin between deep ocean and shelf, the up-welling of nutrient rich deep water is contributing to oceanic production and this is reflected in gas phase boundary layer concentrations. Ideally this type of flight needs to be performed again but penetrating further out into the open ocean in order to determine DMS abundances there. On the basis of data collected here however, the boundary layer over the shelf 15 region was particularly high in DMS and its proximity to $\mathrm{MH}$ makes this a significant influence on DMS observed on shore. The NAMBLEX experiment saw extremely high MH DMS concentrations, up to 800 pptV (Lewis et al., 2005). This was contrast with a maximum of only 200 pptV in 1996 (the year of work reported in Bassford et al. (1999) and Baker et al. (2000), 40 pptV in summer 1997 and 84 pptV in summer 1999. It is therefore not possible to conclude whether the NAMLBEX DMS conditions are entirely typical, and the question of local versus long range DMS arriving at $\mathrm{MH}$ remains difficult to resolve.

Less is known about the production mechanism of alkenes in sea water but it has been suggested that they are produced by a photochemical mechanism acting on dissolved organic carbon (Ratte et al., 1995; Lewis et al., 1999). The relatively constant boundary layer concentration of ethene over this region confirms an unrelated source to DMS and suggests widespread production and evasion from the ocean surface is occurring irrespective of location. This would be in line with observations reported in Lewis et al. (2001) from the Cape Grim observatory, which is adjacent to deep open

\section{ACPD}

$5,12505-12530,2005$

\section{SNAP}

R. M. Purvis et al.

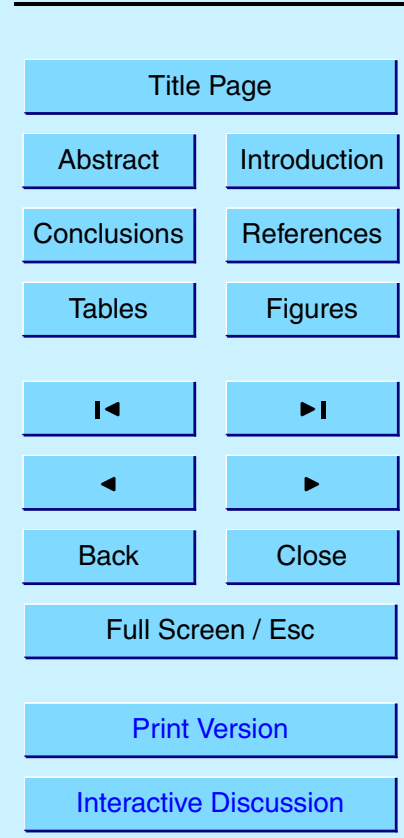

EGU 
ocean. In this location diurnal cycles were observed in most marine airmasses. Once again observations with greater penetration into the open ocean beyond the shelf would help confirm this.

\section{Conclusions}

5 Vertically resolved observations over Mace Head indicate that the ground based measurements of ozone and NMHCs are closely aligned to those seen in the middle boundary layer directly over the site. The data suggests that at least for these species, there is no significant influence due to intertidal zone or topographic effects. A significant discrepancy between $\mathrm{CO}$ observations was seen but the cause of the differences could not be established in this study. Assuming a constant offset between instruments however it would appear that these observations also agree between surface and $390 \mathrm{~m}$. The vertical profile flight indicated a range of airmass characteristics over a $3.2 \mathrm{~km}$ altitude range above $\mathrm{MH}$, with marine boundary layer influence observed on occasion at altitudes greater than $3 \mathrm{~km}$. The influence of small convective events in introducing chemicals from marine sources to the free troposphere is therefore clearly important but difficult to recreate using only a trajectory based interpretation of airmass origin. Observations made of trace gas distributions over the ocean region to the continental shelf indicated once again that convective uplift of occurred regularly under the cloudy westerly conditions encountered but was geographically very patchy. The measure-

ments of DMS within the boundary layer over continental shelf and open ocean regions were limited by aircraft range and penetration into deep ocean regions were less than optimal. However a significant maxima in DMS was observed in the boundary layer over the margins of the shelf itself and adjacent coast waters, decreasing towards $\mathrm{MH}$. A possible explanation may be the up welling of nutrient rich water from the deep ocean
ACPD

$5,12505-12530,2005$

SNAP

R. M. Purvis et al.

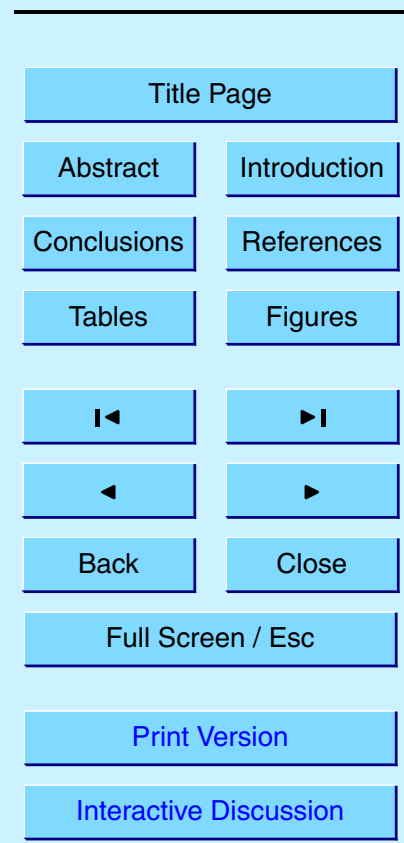

EGU the gas phase. If typical of western Atlantic conditions this would indicate that emissions from the shelf region may play a substantial role in determining concentrations of 
Acknowledgements. We would like to thank the team from the NERC Airborne Remote Sensing Facility for their assistance and support for this work. We would like to thank G. Spain 5 for the provision of ozone and CO data from the Mace Head observatory, and to D. Heard for coordination of the NAMBLEX field experiments. P. Monks is thanked for the loan of the ozone instrument for the in-situ measurements. The British Atmospheric Data Centre are acknowledged for providing data management resources. This work was supported by the UK Natural Environment Research Council and The authors gratefully acknowledge the NOAA Air

10 Resources Laboratory (ARL) for the provision of the HYSPLIT transport and dispersion model (http://www.arl.noaa.gov/ready.html) used in this publication. A. Wilson (CEH, Monks Wood, UK) is thanked for the provision of the GPS data. The SNAP project was made possible through the NERC ARSF Annual Flying hours program.

\section{References}

15 Anderson, T. L., Wolfe, G. V., and Warren, S. G.: Biological Sulfur, Clouds and Climate, Encyclopedia of Earth System Science, 1, 363-376, Academic Press, Inc., 1992.

Atkinson R.: Gas-phase tropospheric chemistry of volatile organic compounds. 1. Alkanes and alkenes, J. Phys. Chem Ref. Data., 26, 215-290, 1997.

Bassford, M. R., Nickless, G., Simmonds, P. G., Lewis, A. C., Pilling, M. J., and Evans, M. J.: 20 The concurrent observation of methyl iodide and dimethyl sulphide in marine air; implications for sources of atmospheric methyl iodide, Atmos. Environ., 33, 2373-2383, 1999.

Baker, A. R., Turner, S. M., Broadgate, W. J., Thompson, A., McFiggans, G. B., Vesperini, O., Nightingale, P. D., Liss, P. S., and Jickells, T. D.: Distribution and sea-air fluxes of biogenic trace gases in the eastern Atlantic Ocean, Global Biogeochem. Cycles, 14, 871-886, 2000.

Blake, N. J., Blake, D. R., Wingenter, O. W., Sive, B. C., Kang, C. H., Thornton, D. C., Bandy, A. J., Atlas, E. L., Flocke, F., Harris, J. M., and Rowland, F. S.: Aircraft measurements of the latitudinal, vertical and seasonal variations of NMHCs, methyl nitrate, methyl halides, and DMS during the First Aerosol Characterization Experiment (ACE 1), J. Geophys. Res., 104, 21803-21817, 1999.

\section{SNAP}

R. M. Purvis et al.

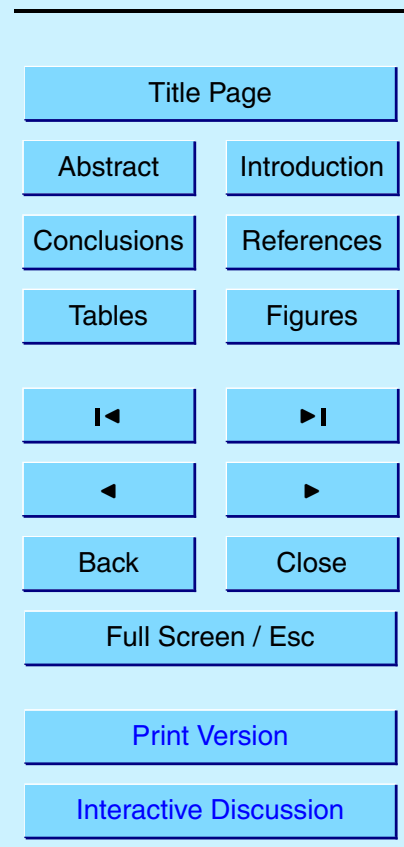

EGU 
Bonsang, B. and Lambert, G.: Nonmethane Hydrocarbons in an Oceanic Atmosphere, J. Atmos. Chem., 2, 257-271, 1985.

Bonsang, B., Martin, D., Lambert, G., Kanakidou, M., Roulley, J. C. L., and Sennequier, G.: Vertical Distribution of non methane hydrocarbons in the remote marine boundary layer, J.

5 Geophys. Res., 96, 7313-7324, 1991.

Broadgate, W. J., Liss, P. S., and Penkett, S. A.: Seasonal Emissions of isoprene and other reactive Hydrocarbon Gases from the Ocean, Geophys. Res. Lett., 24, 2675-2678, 1997.

Carpenter, L. J., Sturges, W. T., Penkett, S. A., Liss, P. S., Alicke, B., Hebestreit, K., and Platt, U.: Short-lived alkyl iodides and bromides at Mace Head, Ireland: Links to biogenic sources and halogen oxide production, J. Geophys. Res., 104, 1679-1689. 1999.

Carslaw, N., Creasey, D. J., Heard, D. E., Lewis, A. C., McQuaid, J. B., Pilling, M. J., Monks, P. S., Bandy, B. J., and Penkett, S. A.: Modeling $\mathrm{OH}, \mathrm{HO}_{2}$, and $\mathrm{RO}_{2}$ radicals in the marine boundary layer -1 . Model construction and comparison with field measurements, $\mathrm{J}$. Geophys. Res., 104, 30 241-30255, 1999.

15 Charleston, R. J., Lovelock, J. E., Andreae, M. O., and Warren, S. G.: Oceanic phytoplankton, atmospheric sulphur, cloud albedo and climate, Nature, 326, 655-661, 1987.

Clarke, A. D., Varner, J. L., Eisele, F., Mauldin, R. L., Tanner, D., and Litchy, M.: Particle production in the remote marine atmosphere: Cloud outflow and subsidence during ACE 1, J. Geophys. Res., 103, 16 397-16 409, 1998.

20 Crutzen, P. J. and Andreae, M. O.: Biomass burning in the tropics: Impact on atmospheric chemistry and biogeochemical cycles, Science, 250, 1669-1678, 1990.

Derwent, R. G., Simmonds, P. G., Seuring, S., and Dimmer, C.: Observation and interpretation of the seasonal cycles in the surface concentrations of ozone and carbon monoxide at Mace Head, Ireland from 1990 to 1994, Atmos. Environ., 32, 145-157, 1998.

Draxler, R. R. and Rolph, G. D.: HYSPLIT Model access via NOAA ARL READY Website (http: //www.arl.noaa.gov/ready/hysplit4.html), NOAA Air Resources Laboratory, Silver Spring, MD, 2003.

Gerbig, C., Kley, D., Volz-Thomas, A., Kent, J., Dewey, K., and McKenna, D. S.: Fast response fluorescence $\mathrm{CO}$ measurements aboard the C-130: Instrument characterization and mea30 surements made during North Atlantic Regional Experiment 1993, J. Geophys. Res., 101, 29229-29238, 1996.

Gerbig, C., Schmitgen, S., Kley, D., Volz-Thomas, A., Dewey, K., and Haaks, D.: An improved fast response vacuum UV resonance fluorescence CO instrument, J. Geophys. Res., 104,

ACPD

$5,12505-12530,2005$

SNAP

R. M. Purvis et al.

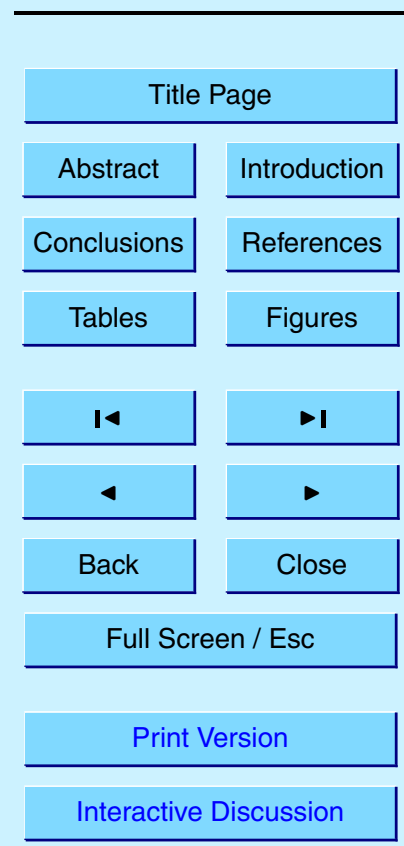

EGU 
1699-1704, 1999.

Harriss, R. C., Sachse, G. W., and Hill, G. F.: Carbon monoxide and methane in the North American Arctic and Subarctic troposphere : July-August 1988, J. Geophys. Res., 97, 16589$16599,1992$.

5 Lewis, A. C., McQuaid, J. B. Carslaw, N., and Pilling, M. J.: Diurnal cycles of short-lived tropospheric alkenes at a north Atlantic coastal site, Atmos. Environ., 33, 2417-2422, 1999.

Lewis, A. C., Bartle, K. D., McQuaid, J. B., Heard, D. E., Pilling, M. J., and Seakins, P. W.: In Situ Diurnal GC Measurements Of NMHC And DMS At A Remote Coastal Location (Mace Head, Eire) July/August 1996, J. Chem. Soc. Faraday Trans., 93, 2921-2927, 1997.

Lewis, A. C., Hopkins, J. R., Carpenter, L. J., Stanton, J., Read, K. A., and Pilling, M. J.: Sources and sinks of acetone, methanol, and acetaldehyde in North Atlantic air, Atmos. Chem. Phys., 5, 1963-1974, 2005, SRef-ID: 1680-7324/acp/2005-5-1963.

Lewis, A. C., Carpenter, L. J., and Pilling, M. J.: Non-Methane Hydrocarbons in Southern 15

Norton, E. G., Vaughan, G., Coe, H., Methven, J., and Brooks, B.: Boundary layer structure and decoupling from synoptic scale flow during NAMBLEX, Atmos. Chem. Phys. Discuss., 5, 3191-3223, 2005, SRef-ID: 1680-7375/acpd/2005-5-3191.

20

Pfister, G., Hess, P. G., Emmons, L. K., Lamarque, J.-F., Wiedinmyer, C., Edwards, D. P., Petron, G., Gille, J. C., and Sachse, G. W.: Quantifying CO emissions from the 2004 Alaskan wildfires using MOPITT CO data, Geophys. Res. Lett., 32, L11809, doi:10.1029/2005GL022995, 2005.

Ratte, M., Plass-Dulmer, C., Koppmann, R., and Rudolph, J.: Horizontal and vertical profile 25 of light hydrocarbons in seawater related to biological, chemical and physical parameters, Tellus, 5 47B, 607-623, 1995.

Read, A., Heard, E., Methven, J., et al.: The North Atlantic Marine Boundary Layer Experiment (NAMBLEX). Overview of the campaign held at Mace Head, Ireland, in summer 2002, Atmos. Chem. Phys. Discuss., accepted, 2005.

30 Saiz-Lopez, A. and Plane, J. M. C.: Novel iodine chemistry in the marine boundary layer, Geophys. Res. Lett., 31, 04112, doi:10.1029/2003GL019215, 2004.

Shaw, S. L., Chisholm, S. W., and Prinn, R. G.: Isoprene production by Prochlorococcus, a marine cyanobacterium, and other phytoplankton, Marine Chem., 80, 227-245, 2003.

\section{ACPD}

$5,12505-12530,2005$

\section{SNAP}

R. M. Purvis et al.

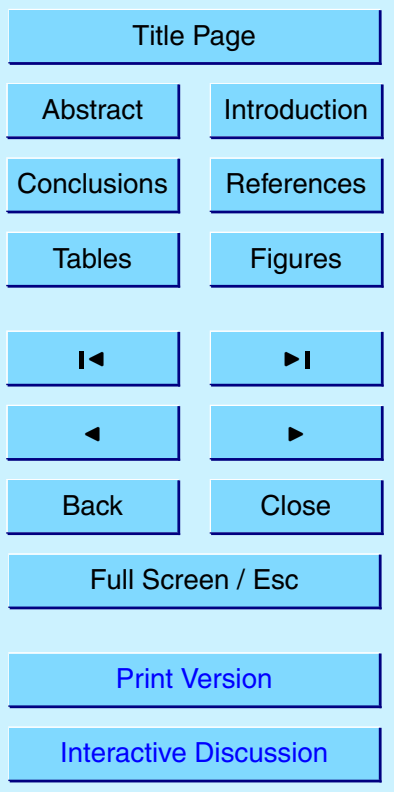

EGU 
Simmonds, P. G., Derwent, R. G., Manning, A. L., and Spain, G.: Significant growth in surface ozone at Mace Head, Ireland, 1987-2003, Atmos. Environ., 38, 4769-4778, 2004.

Sweeney, B. and Stacey, B.: Intercomparison and intercalibration techniques employed for the UK National air monitoring networks, Warren Spring Laboratory Report, Stevenage, UK, 1992.

Waibel, A. E., Fischer, H., Wienhold, F. G., Siegmund, P. C., Lee, B., Strom, J., Lelieveld, J., and Crutzen, P. J.: Highly elevated carbon monoxide concentrations in the upper troposphere and lower most stratosphere at northern midlatitudes during the STREAM II summer campaign in 1994, Chemosphere: Global Change Science, 1 (1-3), 233-248, 1999.

10 Wang, Q., Suhre, K., Krummel, P., Siems, S., Pan, L., Bates, T. S., Johnson, J. E., Lenschow, D. H., Heubert, B. J., Kok, G. L., Schillawski, R. D., Prevot, A. S. H., and Businger, S.: Characteristics of marine boundary layers during two Lagrangian measurement periods 1. General conditions and mean characteristics, J. Geophys. Res., 104, 21 751-21 765, 1999.

Wotawa, G. and Trainer, M.: The influence of Canadian forest fires on pollutant concentrations 15 in the United States, Science, 288, 324-328, 2000.

\section{ACPD}

$5,12505-12530,2005$

\section{SNAP}

R. M. Purvis et al.

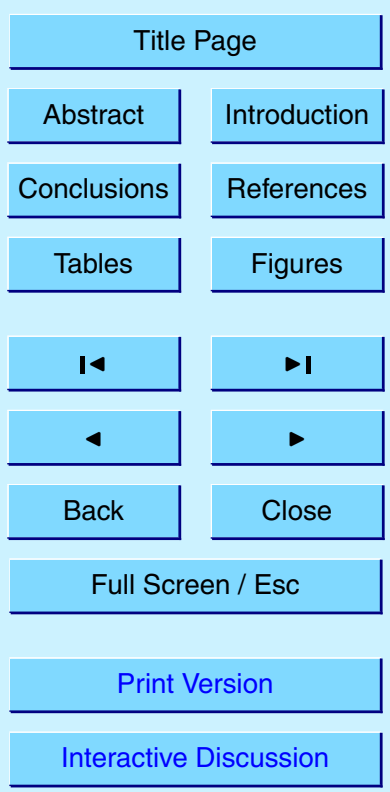




\section{ACPD}

5, 12505-12530, 2005

SNAP

R. M. Purvis et al.

Table 1. Details of flights in this study.

\begin{tabular}{ccc}
\hline Flight & Date & Investigation \\
\hline Continental Shelf (CS1) & 8 August 2002 & $\begin{array}{c}\text { Distribution of trace species in } \\
\text { coastal and deep sea regions }\end{array}$ \\
Vertical Profile (VP1) & 10 August 2002 & $\begin{array}{c}\text { Several vertical profiles centred } \\
\text { around MH }\end{array}$ \\
\hline
\end{tabular}

\begin{tabular}{|c|c|}
\hline \multicolumn{2}{|c|}{ Title Page } \\
\hline Abstract & Introduction \\
\hline Conclusions & References \\
\hline Tables & Figures \\
\hline 14 & $\rightarrow 1$ \\
\hline 4 & $\triangleright$ \\
\hline Back & Close \\
\hline \multicolumn{2}{|c|}{ Full Screen / Esc } \\
\hline \multicolumn{2}{|c|}{ Print Version } \\
\hline Interactiv & iscussion \\
\hline
\end{tabular}




\section{ACPD}

$5,12505-12530,2005$

SNAP

Table 2. Comparison of Mace Head measurements and aircraft observations. Data averaged over the full length of level run at $390 \mathrm{~m}$.

\begin{tabular}{ccc}
\hline $\begin{array}{c}\text { Compound } \\
\text { (pptV unless stated) }\end{array}$ & $\begin{array}{c}\text { Ground measurement } \\
\text { at } 20 \mathrm{~m}(\mathrm{n}=4)\end{array}$ & $\begin{array}{c}\text { Aircraft measurement } \\
\text { at } 390 \mathrm{~m}(\mathrm{n}=3)\end{array}$ \\
\hline Ethane & $590.7 \pm 6.6$ & $604.3 \pm 19.1$ \\
Ethene & $18.2 \pm 4.9$ & $19.2 \pm 18.7$ \\
Propane & $58.8 \pm 1.6$ & $55.5 \pm 21.5$ \\
Propene & $6.0 \pm 5.8$ & $12.8 \pm 4.6$ \\
Acetylene & $39.0 \pm 2.0$ & $36.4 \pm 3.3$ \\
iso-Butane & $5.8 \pm 6.8$ & $3.9 \pm 0.6$ \\
$n$-Butane & $19.1 \pm 32.3$ & $4.3 \pm 1.6$ \\
iso-Pentane & $47.3 \pm 2.7$ & $2.4 \pm 2.1$ \\
$n$-Pentane & $18.1 \pm 1.9$ & $1.3 \pm 2.3$ \\
Isoprene & ${ }^{*} \mathrm{BDL}$ & $13.5 \pm 23.5$ \\
DMS & $71.6 \pm 7.1$ & $56.0 \pm 39.3$ \\
ozone $(\mathrm{ppbV})$ & $33.5 \pm 1.3$ & $31.02 \pm 0.7$ \\
CO $(\mathrm{ppbV})$ & $77.8 \pm 0.7$ & $109.32 \pm 0.7$ \\
\hline
\end{tabular}

${ }^{\star} \mathrm{BDL}=$ Below detection limit

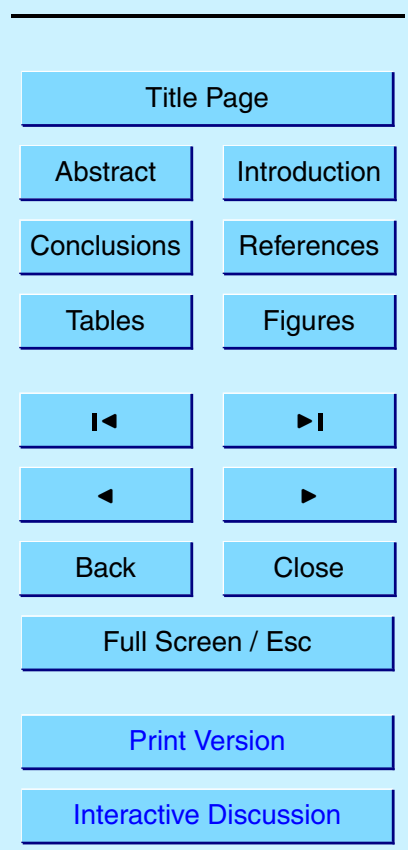

R. M. Purvis et al. 


\section{ACPD}

5, 12505-12530, 2005

SNAP

R. M. Purvis et al.

Table 3. Vertical distribution of trace gases from flight VP1.

\begin{tabular}{cccccc}
\hline $\begin{array}{c}\text { Compound } \\
\text { (pptV unless stated) }\end{array}$ & Run 1 & Run 2 & Run 3 & Run 4 & Run 5 \\
\hline Ethane & 604.3 & 618.0 & 633.3 & 618.6 & 585.6 \\
Ethene & 19.2 & 13.4 & ${ }^{*} \mathrm{BDL}$ & 16.3 & 37.2 \\
Propane & 55.5 & 38.0 & 60.9 & 51.4 & 54.0 \\
Propene & 12.8 & 21.8 & 12.2 & 15.6 & 21.0 \\
Acetylene & 36.4 & 37.8 & 46.0 & 40.0 & 47.0 \\
iso-Pentane & 2.4 & ${ }^{*} \mathrm{BDL}$ & 2.1 & 2.3 & no data \\
n-Pentane & 1.3 & 1.2 & 2.0 & 1.5 & 9.3 \\
Isoprene & 13.5 & 1.7 & ${ }^{*} \mathrm{BDL}$ & 7.6 & 11.5 \\
DMS & 56.0 & 26.8 & 38.9 & 40.6 & 65.8 \\
Ozone (ppbV) & 31.0 & 36.6 & 35.6 & 50.6 & 52.4 \\
CO (ppbV) & 109.3 & 113.4 & 120.4 & 115.5 & 131.2 \\
\hline
\end{tabular}

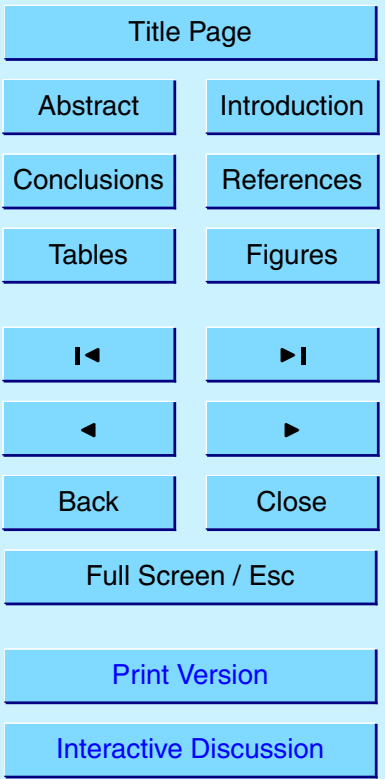

${ }^{*} \mathrm{BDL}=$ Below detection limit 


\section{ACPD}

$5,12505-12530,2005$

\section{SNAP}

R. M. Purvis et al.

Table 4. Selected NMHC, DMS, CO and ozone observed in MBL and FT during CS1.

\begin{tabular}{cccc}
\hline $\begin{array}{c}\text { Run \# } \\
\text { Parameter }\end{array}$ & $\begin{array}{c}\mathrm{FT} \\
(3.2 \mathrm{~km} \text {, full run })\end{array}$ & $\begin{array}{c}\mathrm{MBL} \\
(4-600 \mathrm{~m} \text {, shelf region })\end{array}$ & $\begin{array}{c}\mathrm{MBL} \\
(\sim 430 \mathrm{~m}, \text { coastal })\end{array}$ \\
\hline $\mathrm{n}$ & 14 & 3 & 3 \\
Start/End (UT) & $14: 00 / 15: 05$ & $15: 20 / 15: 35$ & $16: 20 / 16: 40$ \\
Distance (km) & 174 & 40 & 54 \\
Ethane (pptV) & $683.1( \pm 53.9)$ & $647.0( \pm 18.9)$ & $668.0( \pm 43.9)$ \\
Ethene (pptV) & $42.6( \pm 35.8)$ & $16.9( \pm 4.6)$ & $52.4( \pm 15.1)$ \\
Propane (pptV) & $67.8( \pm 91.2)$ & $49.5( \pm 8.0)$ & $78.0( \pm 10.2)$ \\
Propene (pptV) & $39.9( \pm 70.8)$ & $19.1( \pm 9.4)$ & $37.4( \pm 20.9)$ \\
iso-Butane (pptV) & $8.6( \pm 15.0)$ & $5.4( \pm 1.5)$ & $17.2( \pm 0.5)$ \\
n-butane (pptV) & no data & $5.6( \pm 1.2)$ & $28.7( \pm 16.8)$ \\
Acetylene (pptV) & $64.9( \pm 25.4)$ & $44.7( \pm 5.1)$ & $69.6( \pm 6.7)$ \\
DMS (pptV) & $79.9( \pm 236.5)$ & $187.0( \pm 26.9)$ & $30.6( \pm 6.0)$ \\
CO (ppbV) & $106.3( \pm 114.4)$ & $102.6( \pm 107.1)$ & $100.0( \pm 103.5)$ \\
Ozone (ppbV) & $39.8( \pm 84.3)$ & $32.3( \pm 34.3)$ & $36.4( \pm 41.3)$ \\
\hline
\end{tabular}

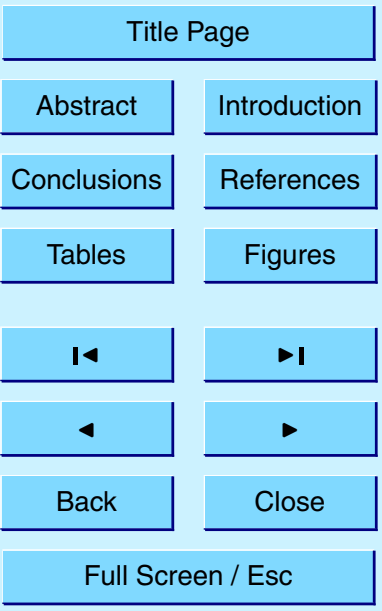

Print Version

Interactive Discussion

EGU 


\section{ACPD}

$5,12505-12530,2005$

SNAP

R. M. Purvis et al.
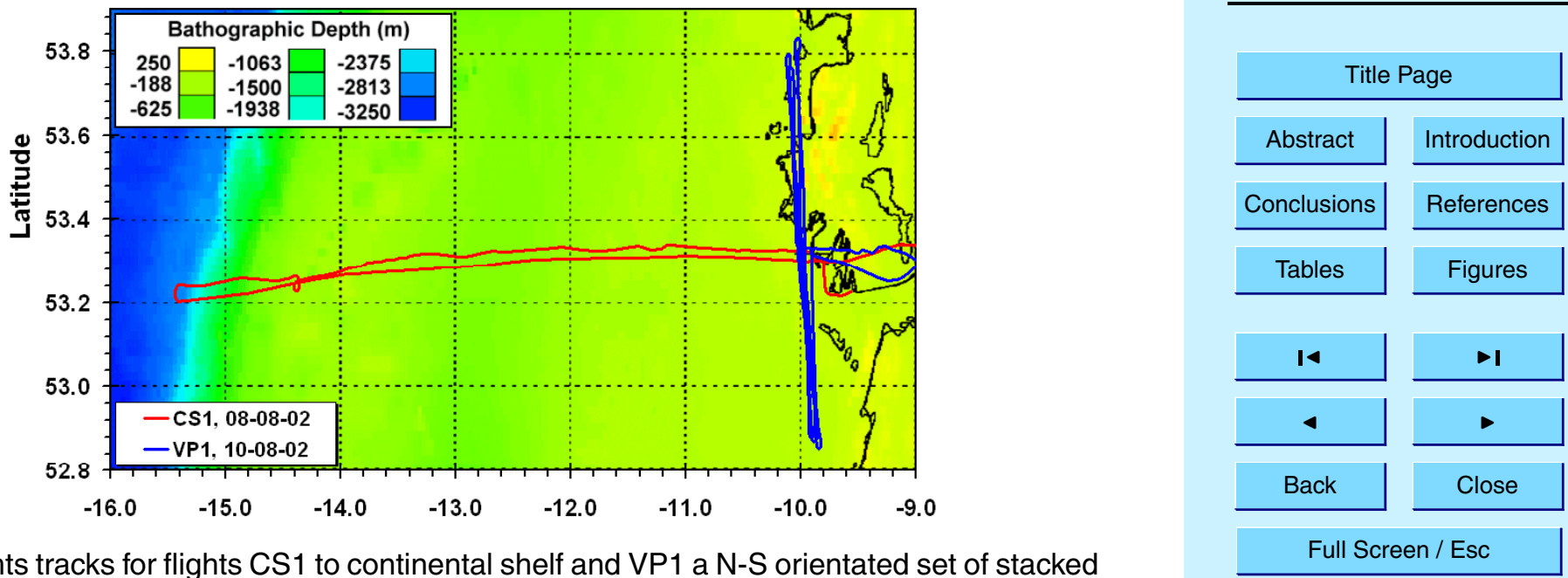

Fig. 1. Flights tracks for flights CS1 to continental shelf and VP1 a N-S orientated set of stacked profiles centred over the Mace Head Observatory.

Print Version

Interactive Discussion

EGU 

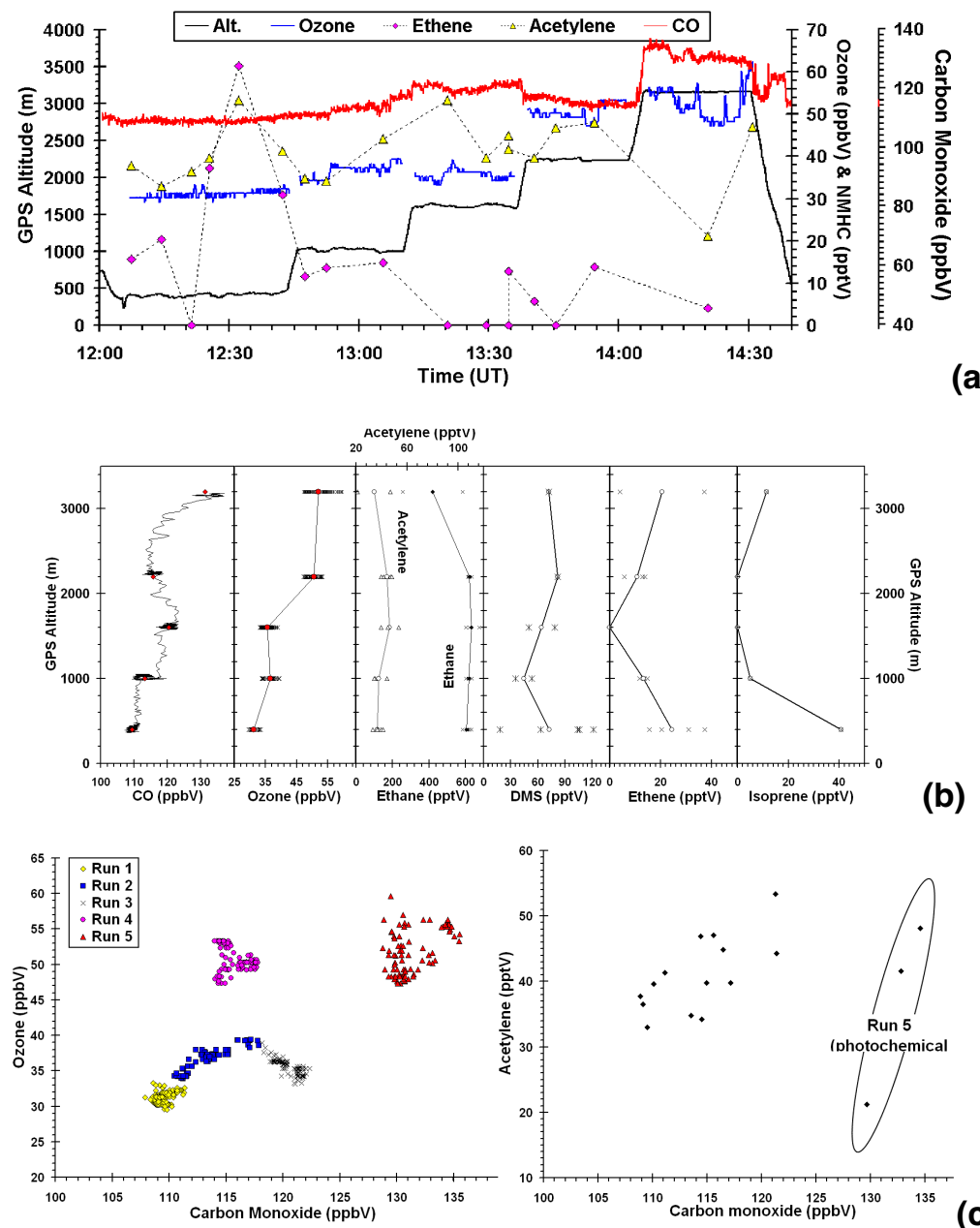

(c)

\section{ACPD}

$5,12505-12530,2005$

SNAP

R. M. Purvis et al.

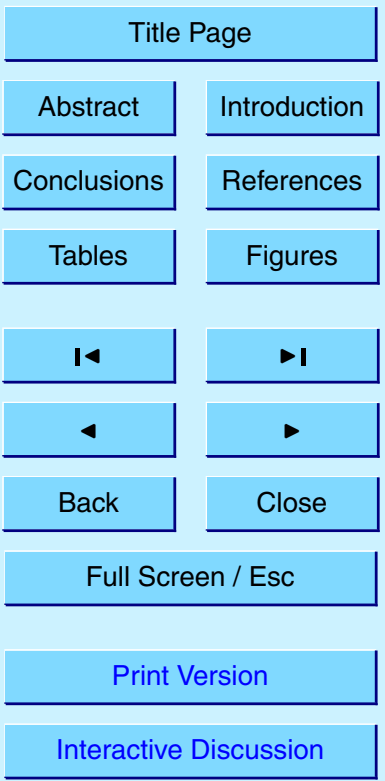

EGU

Fig. 2. (a) Time series for flight VP1 showing altitude, CO, ozone, ethene and acetylene. (b) Vertical profiles of selected species observed during VP1. (c) Ozone/CO and Acetylene/CO correlations during VP1. 


\section{ACPD}

5, 12505-12530, 2005

SNAP

R. M. Purvis et al.

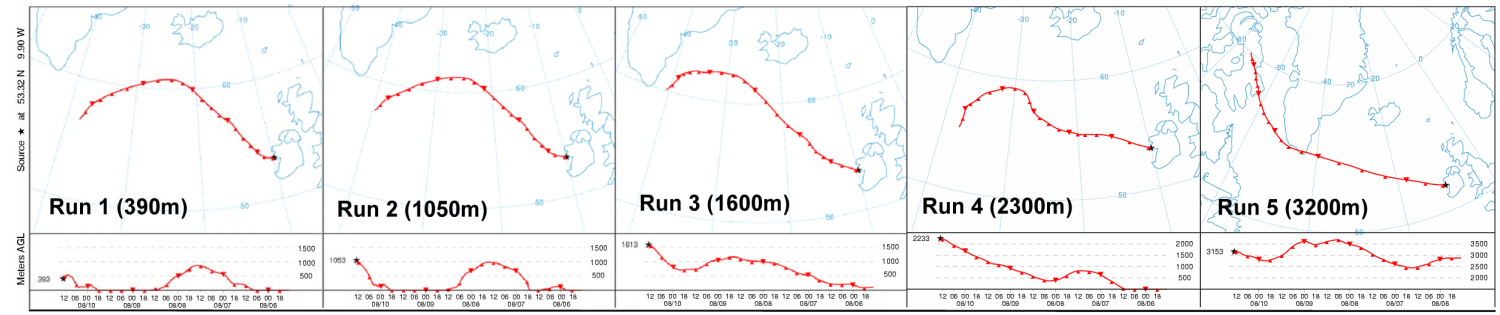

\begin{tabular}{|c|c|}
\hline \multicolumn{2}{|c|}{ Title Page } \\
\hline Abstract & Introduction \\
\hline Conclusions & References \\
\hline Tables & Figures \\
\hline 14 & $>1$ \\
\hline 4 & 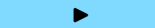 \\
\hline Back & Close \\
\hline Full & / Esc \\
\hline
\end{tabular}

Fig. 3. 5 day back trajectories for Runs 1-5 during flight VP1.

Print Version

Interactive Discussion 


\section{ACPD}
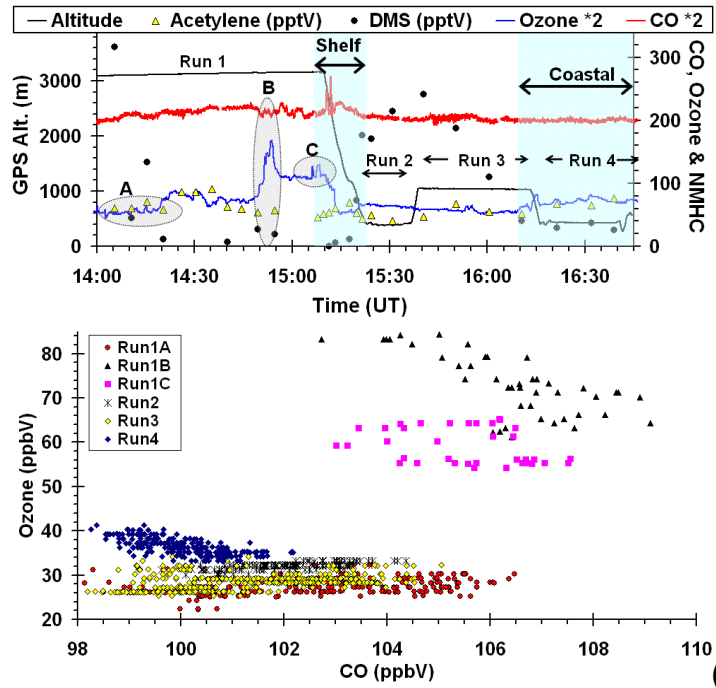

(a)

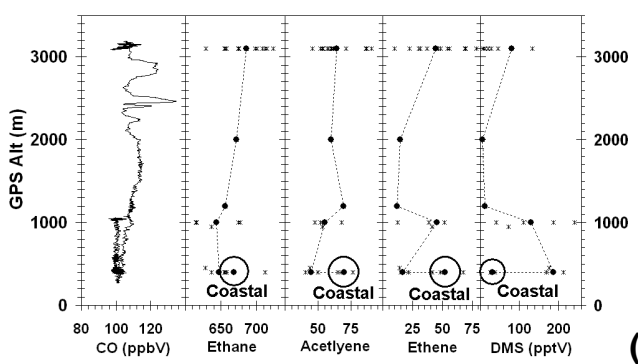

(b)

$5,12505-12530,2005$

SNAP

R. M. Purvis et al.

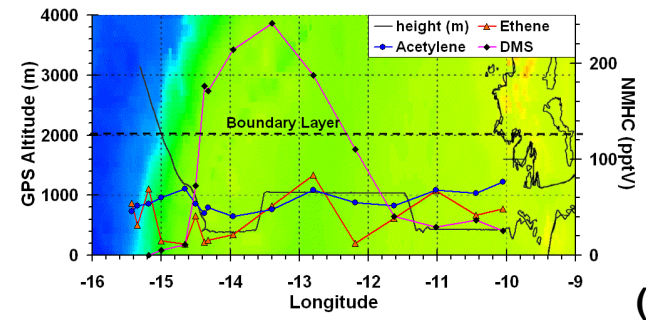

(d)

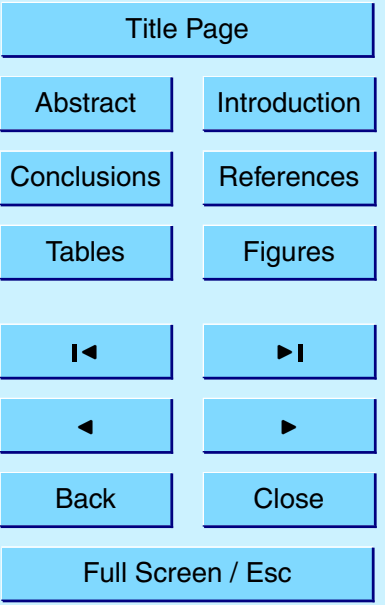

Fig. 4. (a) Time series for Flight CS1 showing ozone, CO, DMS and acetylene; The shelf and coastal areas are also indicated. (b) Vertical profiles of selected species observed during CS1. (c) Ozone/CO correlations for CS1. (d) Distribution of selected species from the shelf region to the $\mathrm{MH}$ site with approximate $\mathrm{BL}$ height; background is coloured by ocean depth.

Print Version

Interactive Discussion 